\title{
The Long Non-Coding RNA CRNDE Promotes Colorectal Carcinoma Progression by Competitively Binding miR-217 with TCF7L2 and Enhancing the Wnt/ $\beta$-Catenin Signaling Pathway
}

\author{
Bo Yu $u^{a, b}$ Xuan Ye $e^{a, b}$ Qiong Dua,b Bin Zhu ${ }^{a, b}$ Qing Zhaia,b Xin-Xiang Lia,c \\ ${ }^{a}$ Department of Oncology, Shanghai Medical College, Fudan University, Shanghai, ${ }^{b}$ Department of \\ Pharmacy, Fudan University Shanghai Cancer Center, Shanghai, cDepartment of Colorectal Surgery, \\ Fudan University Shanghai Cancer Center, Shanghai, China
}

\section{Key Words}

Colorectal cancer • Long non-coding RNAs • miR-217L • TCF7L2 • Wnt/ $\beta$-catenin signaling pathway

\begin{abstract}
Background/Aims: The long non-coding RNA colorectal neoplasia differentially expressed (CRNDE) contributes to the proliferation and migration of tumors. However, its molecular mechanism underlying gastric cancer remains unknown. In the present study, we investigated whether CRNDE was involved in the development of colorectal cancer via the binding of microRNA (miR)-217 with transcription factor 7-like 2 (TCF7L2) to enhance the Wnt signaling pathway. Methods: Quantitative polymerase chain reaction was used to detect CRNDE, miR-217 and TCF7L2 in colorectal cancer tissues and cells. The CCK-8 assay, wound healing assay, and Transwell assay were used to detect cell proliferation, migration and invasion, respectively. Western blotting and luciferase activity assays were used to identify CRNDE and TCF7L2 as one of the direct targets of miR-217. The activity of the Wnt/ $\beta$-catenin signaling pathway was analyzed by the TOPflash assay, and the subcellular localization of $\beta$-catenin and TCF7L2 was analyzed by western blotting and confocal microscopy. Results: In this study, we found that high expression of CRNDE is negatively correlated with low expression of miR-217 in colorectal cancer tissue and colorectal cancer cells. The dual luciferase reporter analysis showed that miR-217 is bound to CRNDE and TCF7L2 and negatively regulate their expression. CRNDE down-regulation inhibited the cell proliferation, migration and invasion in vitro and in vivo and the inhibitions were both completely blocked after miR-217 inhibition or TCF7L2 overexpression. Finally, TOPflash analysis showed that the activity of Wnt/ $\beta$-catenin signaling is inhibited by CRNDE down-regulation and rescued by TCF7L2 over-expression. Consistently, immunostaining and western blotting analysis showed that the expression of B. Yu and X. Ye contributed equally to this work.
\end{abstract}

Qing Zhai and Xin-Xiang Li Department of Pharmacy, Fudan University Shanghai Cancer Center, 270 Dong-An Road, Shanghai; and Department of Oncology, Shanghai Medical College, Fudan University, Shanghai 200032 (China) and Department of Colorectal Surgery, Fudan 


\section{Cellular Physiology Cell Physiol Biochem 2017;41:2489-2502 and Biochemistry Published online: May 04, $2017 \quad \begin{aligned} & \text { D 2017 The Authors. } \\ & \text { www.karger.com/cpb }\end{aligned}$ \\ Yu et al.: CRNDE Promotes Colorectal Carcinoma Progression}

b-catenin and TCF7L2 in the nucleus was significantly decreased by CRNDE down-regulation and was rescued by TCF7L2 over-expression. Conclusions: The present study suggest that CRNDE involves in the cell proliferation, migration and invasion of colorectal cancer cells via increasing the expression of TCF7L2 and activity of Wnt/ $\beta$-catenin signaling through binding miR-217 competitively.

\section{Introduction}

Colorectal cancer (CRC) is a common cause of cancer death in the world due to late tumor presentation and rapid progression [1-4]. There are approximately 14.1 million worldwide new cancer cases and 8.2 million cancer deaths in 2012 [4]. In economically developing countries, CRC is becoming more prevalent, especially in China $[5,6]$. However, the molecular mechanisms underlying CRC progression remain largely unclear.

More than $90 \%$ of the DNA sequence is actively transcribed, but only $2 \%$ encodes protein; thus, most transcripts are as non-coding RNAs (ncRNAs) [7, 8], some of which are involved in malignant transformation and/or cancer progression [9-12]. Based on size, noncoding RNAs are divided into two groups: small ncRNAs, such as microRNAs (miRNAs, 22 nucleotides), which regulate gene expression and are involved in tumorigenesis [13-20], and long non-coding RNAs (lncRNAs, greater than $200 \mathrm{nt}$ ). LncRNAs are involved in various physiological and cellular processes such as development, growth, cell cycle progression, differentiation, inflammation, tumorigenesis, migration and invasion [9-12, 21-23]. Colorectal neoplasia differentially expressed (CRNDE) was initially identified as an lncRNA in colorectal cancer and was found to be located on chromosome 16, which is important in the proliferation, migration, and invasion of colorectal tumor cells [24-28]. Nonetheless, little is known regarding the biological role of CNRDE in the process of colorectal cancer.

Several studies have shown that IncRNAs may interact with miRNAs and mutually modulate their expressions [29]. They may function as competing endogenous RNAs (ceRNAs) with miRNAs and subsequently regulate protein coding gene expression by the posttranscriptional silencing of specific target RNAs [13-15, 30]. An interaction of IncRNAs with miRNAs is involved in cancer pathogenesis [31-33]. This interaction provides new insight into cancer biology.

Here we show that high expression of CRNDE is negatively correlated with low expression of miR-217 in colorectal cancer tissue and colorectal cancer cells. Furthermore, CRNDE down-regulation inhibited the cell proliferation, migration and invasion in vitro and in vivo and the inhibitions were both completely blocked after miR-217 inhibition or TCF7L2 overexpression. Dual luciferase reporter analysis showed that miR-217 is directly bound to CRNDE and TCF7L2 and negatively regulate their expression. Moreover, TOPflash analysis, immunostaining and western blotting showed that the activity of Wnt/ $\beta$-catenin signaling is inhibited by CRNDE down-regulation and rescued by TCF7L2 over-expression. These results suggest that CRNDE is involved in the development of colorectal cancer cells via miR-217 mediated $W n t / \beta$-catenin regulation.

\section{Materials and Methods}

\section{Specimen collection}

Twenty-one pairs of colorectal specimens, including twenty-one human colorectal adenocarcinoma cancer tissues and twenty-eight adjacent tissues, were obtained from the Fudan University Shanghai Cancer Center. The detailed clinicopathological characteristics of the recruited patients are summarized in Table S1, for all online suppl. material, see www.karger.com/doi/ 10.1159/000475941. This study was approved by the Ethics Committee of Fudan University Shanghai Cancer Center. 


\section{Cellular Physiology Cell Physiol Biochem 2017;41:2489-2502

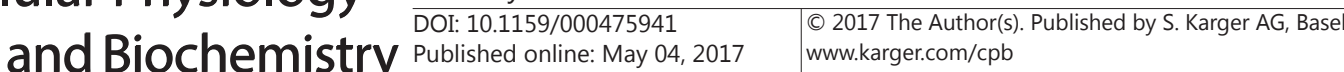

Yu et al.: CRNDE Promotes Colorectal Carcinoma Progression

\section{Cell lines and reagents}

The normal human colon mucosal epithelial cell line NCM460, a series of human colorectal cancer cell lines (HT-29, SW480, HCT-116, SW620, LoVo, SW48, DLD-1, Caco2 and HT-15) and the HEK-293T cell line were purchased from American Type Culture Collection (ATCC, Manassas, VA, USA). All the cells were grown in Dulbecco's Modified Eagle's Medium (DMEM) containing 10\% fetal bovine serum (FBS; Gibco/Thermo Fisher Scientific, Grand Island, NY, USA) and 100 units $/ \mathrm{mL}$ penicillin and streptomycin (Gibco) at $37^{\circ} \mathrm{C}$ in a humidified incubator containing $5 \% \mathrm{CO}_{2}$.

\section{Constructs used to down-regulate CRNDE in HCT-116 and Caco2 cell lines}

The design and cloning of lentiviral shRNA vectors: The target siRNAs against human CRNDE (GenBank, NR_034105.3) for RNAi were designed as follows: siCRNDE, 5'-AGGTGTTAAGTGTGATGCTTCCATA-3'; control RNAi, 5'-TTCTCCCCGAACAACAACGTGTCA-3'. The lentiviral vector system was purchased from Clontech (Mountain View, CA, USA). The vector system included three plasmids: the pLVX-U6-puro vector, psPAX, and pMD2G. The targeting sequence was subcloned into the pLVX-U6-puro vector, which contained the U6 promoter and puromycin gene (puro). The resulting lentiviral vector containing CRNDE shRNA was named shCRNDE, and its sequence was confirmed by polymerase chain reaction (PCR) and sequencing. The lentiviral vector used as the negative control sequence (Con) contained the non-silencing sequence and was used as the infection control for lentiviral vector production and cell infection. Lentiviral vectors were produced by the transient transfection of HEK293 cells according to standard protocols as previously reported [16]. The HEK293 cell line was supplemented with 10\% FBS. When the cells were subconfluent, transfection was accomplished with 1,800 $\mu \mathrm{L}$ of DNA solution containing $10 \mu \mathrm{g}$ of lv-shCRNDE, $10 \mu \mathrm{g}$ of psPAX, and $10 \mu \mathrm{g}$ of pMD2G. All virus stocks were produced by Lipofectamine ${ }^{\circledR}$-mediated transfection. After 48-h posttransfection, the cell supernatants containing viral particles were filtered using the 0.45 $\mu \mathrm{m}$ Steriflip ${ }^{\circledR}$ vacuum filtration system (EMB Millipore, Billerica, MD, USA) and were concentrated by ultracentrifugation at $25,000 \mathrm{rpm}$ at $4^{\circ} \mathrm{C}$. The titer of the virus was tested according to the expression level of green fluorescent protein (GFP). The day before infection, the HCT-116 and Caco2 cells were seeded on dishes at a confluency of 30\%-40\%. On the day of infection, the HCT-116 and Caco2 cells were infected by packaged lentiviral production. Parallel noninfected HCT-116 and Caco2 cells were simultaneously observed. Cells were cultured in normal growth medium for $72 \mathrm{~h}$ after infection. RNAi-NC infection, as a control, was performed as described above. Cells were subsequently propagated in selection medium containing puromycin.

\section{Cell viability assays}

The cell viability was monitored using the Cell Counting Kit-8 (CCK8) assay (Dojindo Molecular Technologies, Kumamoto, Japan) according to the manufacturer's protocol. All the experiments were repeated at least three times.

\section{Wound healing assays}

HCT-116 cells were scraped with a sterile micropipette tip. In the next step, wounded monolayers were washed with phosphate buffer solution (PBS) to remove cell debris. At two time points, the distance between two edges of the wound was calculated at three different positions. In addition, HCT-116 cells were measured at $24 \mathrm{~h}$. The migration rate was calculated as follows: $(\%$ at $0 \mathrm{~h})=\left(\mathrm{D}_{0}-\mathrm{D}_{\mathrm{T}}\right) / \mathrm{D}_{0} \times 100 \%$, where $\mathrm{D}_{0}$ refers to the distance measured at $0 \mathrm{~h}$, and $\mathrm{D}_{\mathrm{T}}$ refers to the distance measured at $24 \mathrm{~h}$.

Transwell invasion assays

Analyses of tumor cell migration and invasion were carried out using Transwell ${ }^{\circledR}$ chambers $(8 \mu \mathrm{m}$; Corning, Corning, NY, USA). A total of $1 \times 10^{5}$ HCT-116 and Caco 2 cells in serum-free medium was collected and seeded in an upper chamber containing a non-Matrigel-coated membrane. Next, $500 \mu \mathrm{L}$ of medium containing 15\% FBS was added to the lower chamber. For the invasion assay, the chambers were coated with extracellular Matrigel (BD Biosciences, San Jose, CA, USA). The cells were cultured at $37^{\circ} \mathrm{C}$ in a humidified incubator with $5 \% \mathrm{CO}_{2}$. Non-invading cells in the upper chamber were removed with a cotton swab, and cells that invaded to the bottom chamber were fixed and stained with $0.1 \%$ crystal violet. Photographs of ten randomly selected fields at $\times 200$ magnifications of the fixed cells were captured, and cells numbers were counted by using ImageJ software (National Institutes of Health, Bethesda, MD, USA). The results were averaged among three independent experiments. 


\section{Cellular Physiology Cell Physiol Biochem 2017;41:2489-2502 and Biochemistry Published online: May 04, $2017 \quad$\begin{tabular}{l|l} 
O 2017 The Authors. \\
www.karger.com/cpb
\end{tabular} \\ Yu et al.: CRNDE Promotes Colorectal Carcinoma Progression}

Xenograft model

HCT-116 and Caco 2 cells $\left(2 \times 10^{\wedge} 6\right.$ in phosphate-buffered saline containing $50 \%$ Matrigel) stably transfected with Lv-CRNDE shRNA or Lv-Scramble were injected subcutaneously into the flanks of BALB/C nude mice ( 6 weeks old, $n=6$ for each group). The volumes of tumors were recorded five days until to 30 days after transplantation day: tumor volume =length $\times$ width ${ }^{2} / 2$. Tumor weight was recorded in transplanted mice at 30 days' post-injection, while the visible neoplastic nodules (spontaneous metastases) on the lungs were counted at 8 weeks' post-injection.

\section{Western blotting}

Freeze-clamped tissues $(50-100 \mathrm{mg})$ or cells $\left(1 \times 10^{\wedge} 6\right)$ were homogenized briefly in 10 volumes of lysis buffer containing $20 \mathrm{mM}$ Tris- $\mathrm{HCl}$ ( $\mathrm{pH}$ 7.4), $150 \mathrm{mM} \mathrm{NaCl}, 2.5$ EDTA mM, $50 \mathrm{mM} \mathrm{NaF}, 0.1 \mathrm{mM} \mathrm{Na}_{4} \mathrm{P}_{2} \mathrm{O}_{7}$, $1 \mathrm{mM} \mathrm{Na} \mathrm{VO}_{4}, 1 \mathrm{mM}$ PMSF, $1 \mathrm{mM}$ DTT, 0.02\% (v/v), protease cocktail (Sigma-Aldrich), 1\% (v/v) Triton $\mathrm{X}-100$, and $10 \%(\mathrm{v} / \mathrm{v})$ glycerol. The homogenates were centrifuged twice at $20,000 \mathrm{~g}$ at $4{ }^{\circ} \mathrm{C}$ for $15 \mathrm{~min}$, and the supernatants were saved as total proteins. The protein concentrations were determined by the bicinchoninic acid assay (BCA) method. Equal amounts of proteins were separated by sodium dodecyl sulfate-polyacrylamide gel electrophoresis (SDS-PAGE) and were transferred to a PVDF membrane (BioRad, Hercules, CA, USA). Western blot analysis was performed under standard conditions with specific antiCARD11 (Ab91463; Abcam, Cambridge, UK) and anti-glyceraldehyde-3-phosphate dehydrogenase (GAPDH) (Ab8245; Abcam) antibodies. The immunoreaction was visualized using an enhanced chemiluminescent detection kit (Amersham, London, UK), exposed to X-ray film, and quantified by densitometry using a video documentation system (Gel Doc 2000, Bio-Rad).

\section{Real-time PCR Analysis}

Total RNA from cells was isolated with the Ultraspec (Biotecx, Houston, TX, USA) according to the manufacturer's instructions. Quantitative PCR analysis was performed using an ABI PRISM 7900 Sequence Detector System (Applied Biosystems, Foster City, CA, USA) as previously described. For the determination of gene expression, the Assay-on-Demand ${ }^{\mathrm{m} \prime}$ system (Applied Biosystems) was used. The transcript levels were normalized to those of GAPDH, which was used as the endogenous control. Each experiment and every determination were performed at least in triplicate, and the levels of gene expression were calculated using the $\Delta \Delta \mathrm{Ct}$ method.

\section{Luciferase reporter assay}

The putative target site of the miR-217 seed sequence in CRNDE (Fig. 3A) and 3'-UTR of TCF7L2 (Fig. $5 \mathrm{~A}$ ) or a mutated variant were cloned into the psiCheck2 firefly luciferase vector (Promega, Madison, WI, USA). The firefly luciferase construct was cotransfected with a control Renilla luciferase vector into HCT116, Caco 2 and HCT-15 cells in the presence of either the miR-217 mimic or scramble. A dual luciferase assay (Promega) was performed $48 \mathrm{~h}$ after transfection. The experiments were performed independently in triplicate.

\section{TOPflash assays}

A $\beta$-catenin/TCF firefly luciferase reporter construct (pTOPflash) and pRL-TK reporter plasmid encoding Renilla luciferase was purchased from Promega (Madison, WI, USA). Cells were seeded onto 12 -well plates at $6 \times 10^{4}$ cells/well and were transiently transfected with $0.2 \mu \mathrm{g}$ of pTOPflash along with $0.02 \mu \mathrm{g}$ of pRL-TK using Lipofectamine ${ }^{\circledR} 2000$ (Invitrogen) following the manufacturer's protocol. The cells were collected $24 \mathrm{~h}$ post-transfection. After lysed and centrifuged, and the supernatant was used for the measurement of luciferase activities using the Dual-Luciferase Assay System (Promega). The firefly luciferase activity was normalized to Renilla luciferase activity and was expressed as the relative luciferase activity.

Statistical analyses

Statistical analyses were conducted using SPSS 21.0 (IBM, Armonk, NY, USA). All statistical tests were two-sided. One-way analysis of variance (ANOVA) was used to compare groups. $p<0.05$ was statistically significant. 


\section{Cellular Physiology Cell Physiol Biochem 2017;41:2489-2502 \begin{tabular}{l|l} 
and 10.1159/000475941 & $\begin{array}{l}\text { @ } 2017 \text { The Author(s). Published by S. Karger AG, Basel } \\
\text { www.karger.com/cpb }\end{array}$ \\
\hline
\end{tabular} \\ Yu et al.: CRNDE Promotes Colorectal Carcinoma Progression}

\section{Results}

CRNDE expression is up-regulated in colorectal cancer tissues and cell lines.

We first analyzed the level of CRNDE expression in colorectal cancer, as shown in Fig. 1A, the CRNDE expression level in colorectal cancer tissue was 3.24-fold that of matched normal tissue $(\mathrm{p}=0.026)$. Based on the expression of CRNDE, these cases were divided into a high CRNDE expression group $(n=10)$ and a low expression group $(n=11)$, based on a CRNDE/ GAPDH ratio of 4.86 in cancerous tissue. The expression of CRNDE was significantly higher in clinical stage III and IV patients than in clinical stage I and II patients $(\mathrm{p}=0.026)$, although no associations were found between CRNDE expression and other clinicopathological features (see supplementary material, Table S2). Compared with NCM460 cells, a normal human colon mucosal epithelial cell line, it was observed that CRNDE was differentially high expressed in a series of cultured colorectal cancer cell lines (LoVo, SW48, DLD-1, Caco2 and HCT-15), with the highest expression in HCT-116 cells, followed by that in Caco2 cells (Fig. 1B). CRNDE expression was almost 26.9-fold and 23.7-fold higher respectively in HCT-116 and Caco 2 cells than that in NCM460 cells. This observation allowed the use of HCT-116 and Caco2 cells as the representative cell lines that were further cultured for subsequent analyses. Collectively, these data suggest that CRNDE was up-regulated in primary colorectal cancer samples.

CRNDE down-regulation inhibits cell proliferation, migration and invasion in colorectal cancer cells in vitro and impairs the tumorigenicity and metastasis in vivo

To demonstrate the role of CRNDE in colorectal cancer cell proliferation, migration, and invasion, a shRNA specifically targeting CRNDE was constructed and transfected into HCT116 and Caco2 cells to down-regulate CRNDE expression. Real-time quantitative PCR was used to confirm the transfection efficiency, which indicated that CRNDE expression in HCT116 and Caco 2 cells transfected with shRNA was $21 \%$ and $15 \%$ of the controls respectively (Fig. 2A). The CCK8 assay showed that shRNA significantly decreased the viability of HCT116 and Caco2 cells (Fig. 2B). In addition, HCT-116 and Caco2 cells with lowered CRNDE expression also had significantly reduced cell migration (Fig. 2C) and invasion capabilities (Fig. 2D). To determine the cell phase of HCT-116 being regulated by CRNDE down-regulation, we analyzed the cell cycle by stained with propidium iodide (PI) and analyzed by flow cytometry. The results indicated that the percentage of cells at G0/G1 phase was significantly higher in CRNDE down-regulated HCT-116 cells than in control cells and the percentage of cell population at G2/M phase was significantly lower in CRNDE down-regulated HCT-116 cells than in control cells, suggesting that CRNDE down-regulation induced G0/G1 cell-cycle arrest in HCT-116 cells (see supplementary material, Fig. S1A). Annexin V/PI staining for detection of apoptosis also revealed that the HCT-116 cells with lowered CRNDE expression had significantly increased apoptosis (see supplementary material, Fig. S1B).

Fig. 1. Colorectal neoplasia differentially expressed (CRNDE) is highly expressed in human colorectal cancer tissue and colorectal cancer cells. (A) The expression of CRNDE in twenty-one pairs of colorectal cancer tissues and corresponding adjacent normal tissues was quanti-

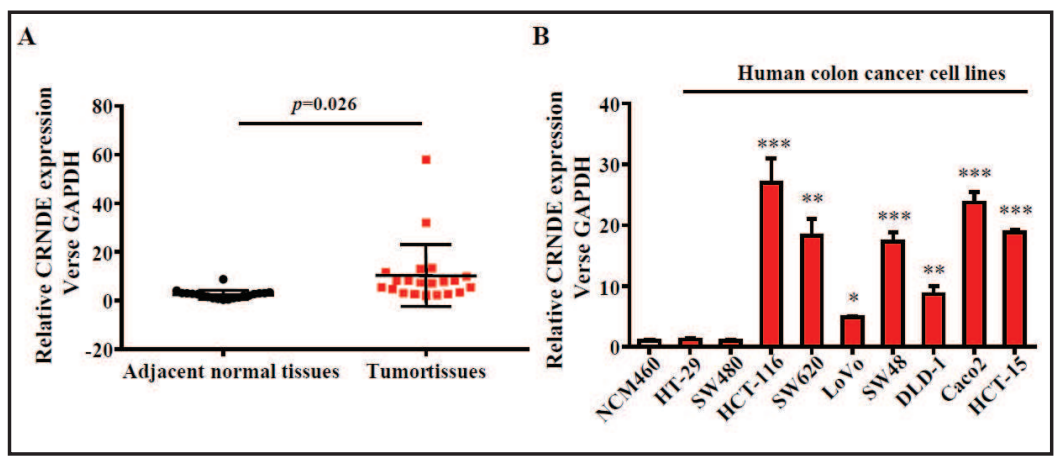
fied by real-time quantitative polymerase chain reaction. (B) Expression of CRNDE was analyzed in a series of human colorectal cancer cell lines (HT-29, SW480, HCT-116, SW620, LoVo, SW48, DLD-1, Caco2 and HCT$15)$ compared to NCM460 cells. The data are expressed as the means $\pm \operatorname{SD}(n=3) .{ }^{*} p<0.05 ;{ }^{* *} \mathrm{p}<0.01$; $^{* * *} \mathrm{p}$ $<0.001$ versus corresponding adjacent normal tissues or NCM460 cell. 


\section{Cellular Physiology Cell Physiol Biochem 2017;41:2489-2502

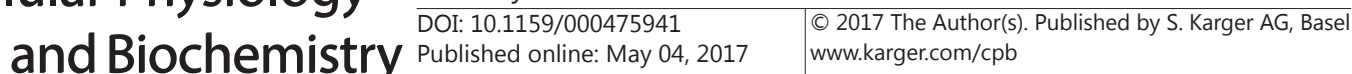 \\ Yu et al.: CRNDE Promotes Colorectal Carcinoma Progression}

Fig. 2. CRNDE down-regulation inhibits cell proliferation, migration and invasion in colorectal cancer cells in vitro and impairs the tumorigenicity and metastasis in vivo. HCT-116 and Caco2 cells were stably transfected with shRNA at a multiplicity of infection (MOI) of 100. The control cells were transfected with an empty vector. (A) The transfection efficiency was confirmed by real-time quantitative PCR. (B) The cell viability was detected by the Cell Counting Kit-8 (CCK-8) assay. (C) The cell migration capability was detected by the wound healing assay. (D) The cell invasion capability was detected by wound healing assay. The data are represented as the means \pm SEM of triplicate independent experiments; ${ }^{*} \mathrm{p}<0.05$; ${ }^{* *} \mathrm{p}<$ 0.01 versus the control group. (E) Tumor growth curve. HCT-116 and Caco2 cells were stably transfected with vector or CRNDE shRNA and then injected into nude mice as described in 'Materials and Methods' section. Tumor growth was measured from day 5 after injection of tumor cells. Tumor weight when tumors were harvested. Error bars represent SEM, $\mathrm{n}=6$; ${ }^{*} \mathrm{p}<0.05 ;{ }^{* *} \mathrm{p}<0.01$ versus the vector control group. (F) After 8 weeks, animals were sacrificed, and the number of visible neoplastic nodules (metastases) on

each lung was counted. Error bars represent SEM, $n=6$; ${ }^{*} p<0.05$ versus the vector control group.
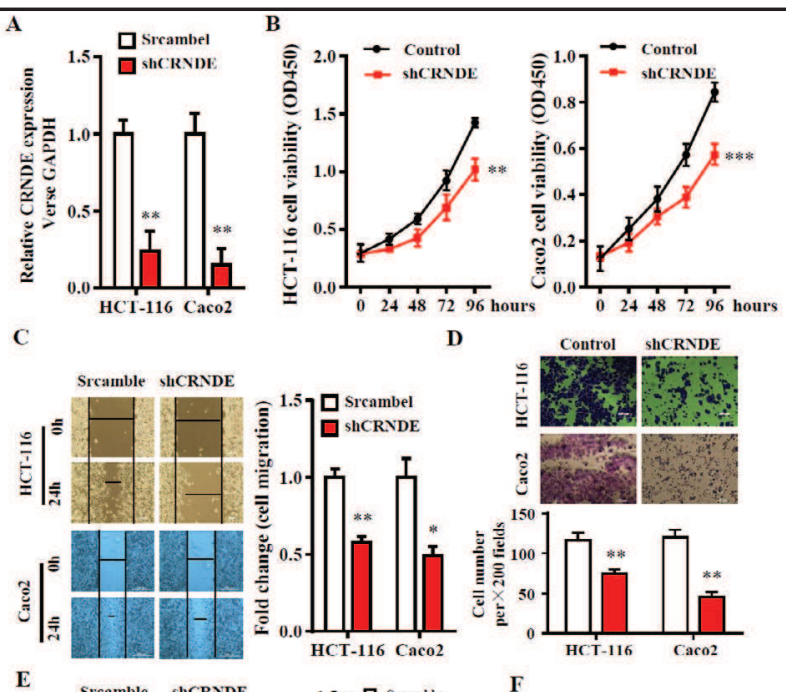

D
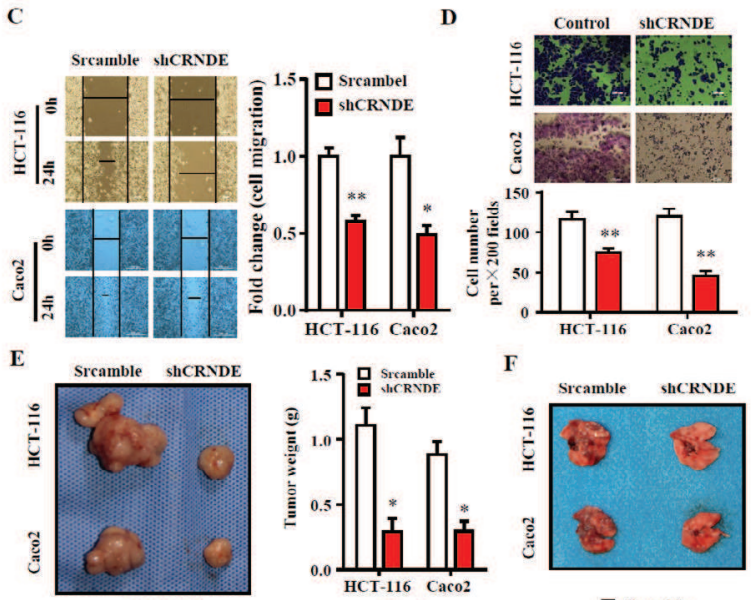

F
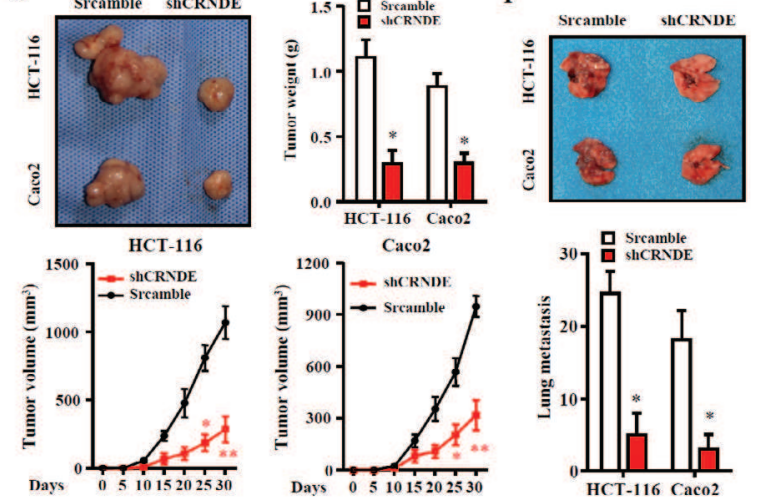

Furthermore, the effect of CRNDE knockdown on colorectal cancer cells tumorigenicity and metastasis in vivo were evaluated in HCT-116 and Caco 2 xenograft models. The growth of the xenografted tumors was measured for 30 days. As shown in Figure 2E, the growth of tumors of CRNDE down-regulated cells was significantly slower than that of controls. Compared with control group, CRNDE down-regulation significantly suppress the final tumor weight at 30 days' post-injection (Fig. 2E). Meanwhile, the number of visible neoplastic nodules (spontaneous metastases) on each lung was counted and evaluated at 8th weeks after inoculation. Significantly fewer lung metastases were observed in CRNDE knockdown xenografts. Collectively, these observations suggested that CRNDE was involved in the regulation of cell proliferation, migration and invasion in vitro and in vivo.

miR-217 directly binds to CRNDE, and the expression levels of miR-217 and CRNDE exhibit an inverse correlation in colorectal cancer tissues and cell lines

To determine the mechanism of action for CRNDE in Colorectal cancer development, we predicted that CRNDE might be associated with the miR-217 binding site $(130-135 \mathrm{bp})$ according to a bioinformatics database (RNA hybrid) (Fig. 3A). Furthermore, a dual luciferase gene reporter assay showed that CRNDE could bind to miR-217 at the predicted binding sites. As shown in Fig. 3B, miR-217 mimic could inhibit the luciferase activity in CRNDE-WT group. But it has no effect in CRNDE-Mut group. These results indicated that miR-217 binds to the transcript position (130-135) of CRNDE. Furthermore, quantitative RT-PCR results demonstrated that miR-217 expression was up-regulated in colorectal cancer tissues (Fig. 3C) and cell lines (Fig. 3D and Fig. S2A, see supplementary material). We also found the 


\section{Cellular Physiology \\ Cell Physiol Biochem 2017;41:2489-2502 and Biochemistry

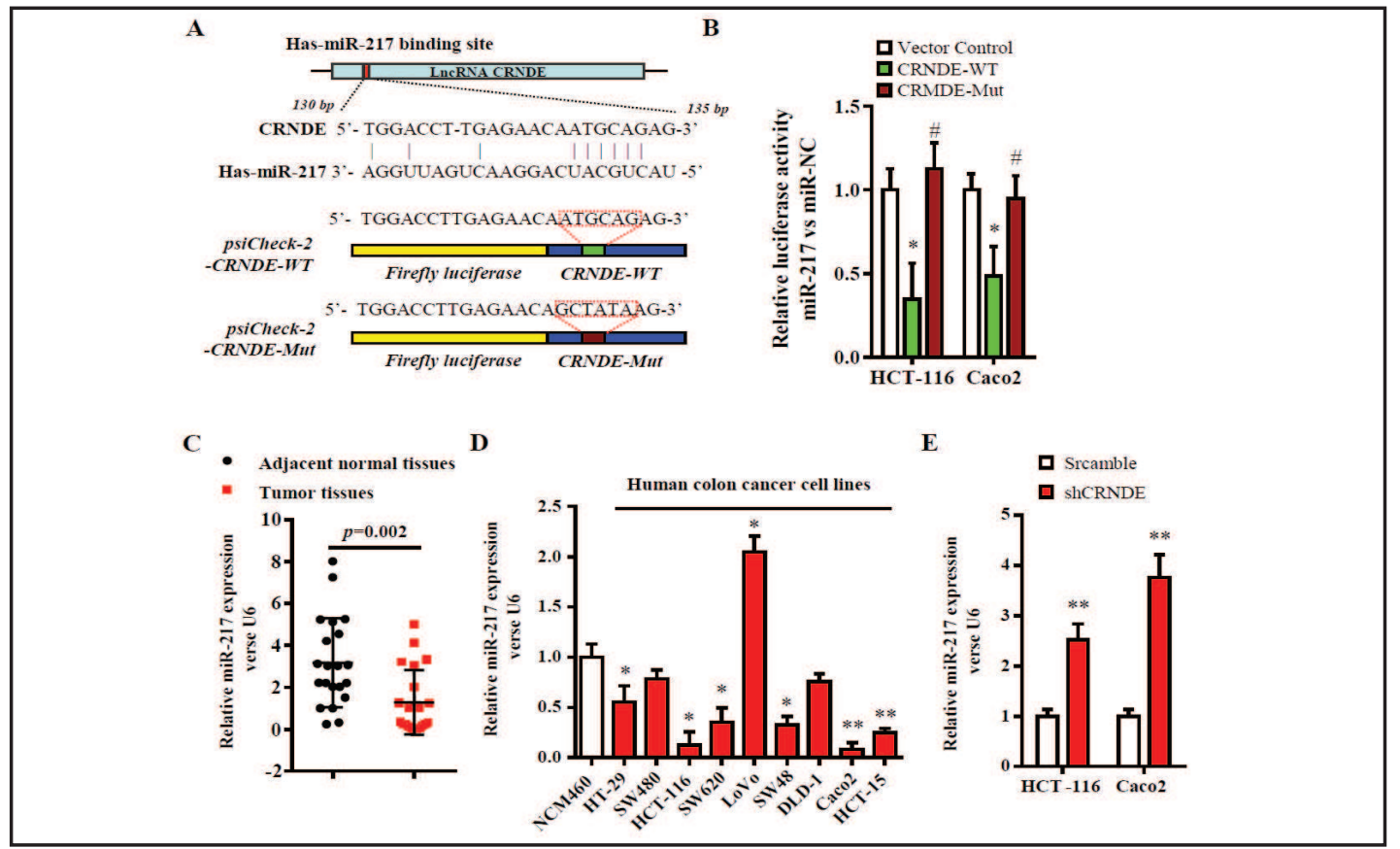

\section{B}

Fig. 3. miR-217 directly binds to CRNDE, and the expression levels of miR-217 and CRNDE exhibit an inverse correlation in colorectal cancer tissues and cell lines. (A) Schematic illustration of the predicted binding sites between CRNDE and miR-217, and mutation of potential miR-217 binding sequence in CRNDE. (B) Luciferase assays in HCT-116 and Caco2 cells transfected CRNDE wild type or mutants with miR-217 mimics. Expression levels of miR-217 was determined by real-time PCR in 21 colorectal cancer tissues (C) and a series of human colorectal cancer cell lines (HT-29, SW480, HCT-116, SW620, LoVo, SW48, DLD-1, Caco2 and HCT-15) (D) compared to those corresponding adjacent normal tissue samples or NCM460 cells. (E)Expression levels of miR-217 as determined by real-time PCR in CRNDE knockdown HCT116 and Caco 2 cells. ${ }^{*} \mathrm{p}<0.05 ;{ }^{* *} \mathrm{p}<0.01$ versus the corresponding control group.

expression of miR-217 was significantly increased in the CRNDE down-regulated HCT-116, Caco2 (Fig. 3E) and HCT-15 cells (see supplementary material, Fig. S2B). Therefore, these results suggest that there is a reciprocal interaction and negative regulation between CRNDE and miR-217.

miR-217 inhibition completely blocks the effect of CRNDE down-regulation on colorectal cancer cells

To understand the role of miR-217 increasing after CRNDE down-regulation in HCT116, Caco 2 and HCT-15, we decreased the expression of miR-217 by the miR-217 inhibitor. Real-time quantitative PCR was used to confirm the inhibition, which indicated that miR217 expression was obviously inhibited (Fig. 4A and Fig. S3, see supplementary material). Amazingly, the down-regulation of miR-217 completely blocked the effect of CRNDE down-regulation with increased cell viability (Fig. 4B), cell migration capability (Fig. 4C), and invasion capability (Fig. 4D) of the HCT-116 and Caco2 cells. These results suggested the increasing level of miR-217 is obviously crucial to the inhibition of cell proliferation, migration and invasion after CRNDE down-regulation.

miR-217 directly target TCF7L2 and negatively regulate its expression

Our data suggested that miR-217 could be a crucial role in the inhibition of cell proliferation, migration and invasion after CRNDE down-regulation in HCT-116 and Caco2 cells. However, its downstream regulation is unknown. To further determine the regulatory role of CRNDE concerning miR-217 and its biological function, we further explored the 


\section{Cellular Physiology Cell Physiol Biochem 2017;41:2489-2502 \begin{tabular}{ll|l} 
and Biochemistry & $\begin{array}{l}\text { DOI: 10.1159/000475941 } \\
\text { Published online: May 04, } 2017\end{array}$ & $\begin{array}{l}\text { ( ) 2017 The Author(s). Published by S. Karger AG, Basel } \\
\text { www.karger.com/cpb }\end{array}$ \\
\hline
\end{tabular}

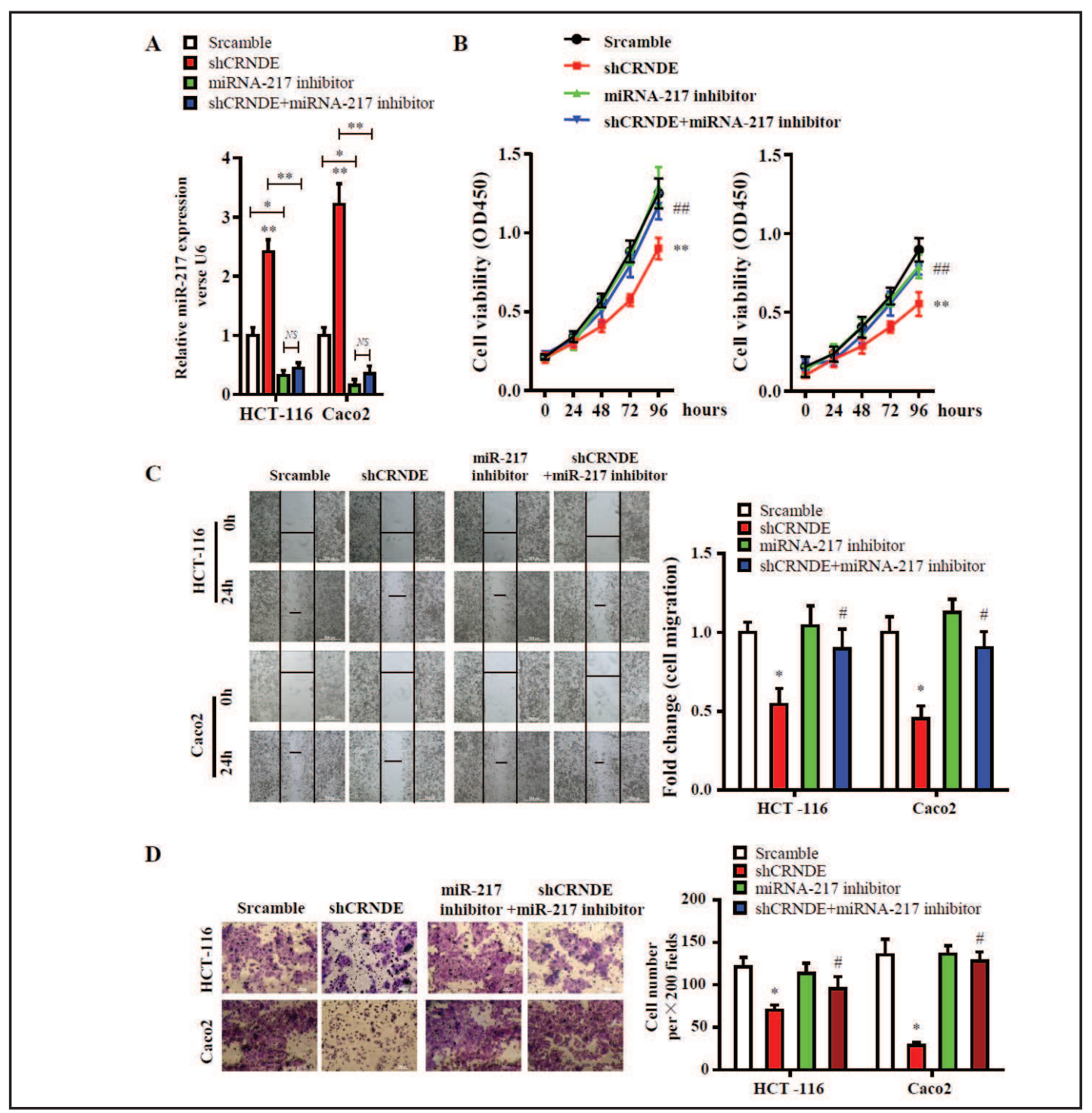

Fig. 4. miR-217 inhibition completely blocks the effect of CRNDE down-regulation on HCT-116 and Caco2 cells. (A) The inhibition of miR-217 was confirmed by real-time quantitative PCR. (B) The cell viability was detected by the Cell Counting Kit-8 (CCK-8) assay. (C) The cell migration capability was detected by the wound healing assay. (D) The cell invasion capability was detected by wound healing assay. The data are represented as the means \pm SEM of triplicate independent experiments. ${ }^{*} p<0.05$; ${ }^{* *} p<0.01$ versus the scrambled group. $\# \mathrm{p}<0.05$ versus the corresponding control miRNA group.

downstream target of miR-217. Through Targetscan6.2 prediction analyses, we identified that TCF7L2 is a highly possible target of miR-217 (Fig. 5A). We next constructed two dual luciferase reporters to verify the putative binding sites (Fig. 5A). In HCT-116, Caco2 and HCT-15 cells, miR-217 effectively reduced the relative luciferase activity of the wild-type reporter, but not that of the reporter carrying the mutant sequence (Fig. 5B and Fig. S4A, see supplementary material). Moreover, knockdown of endogenous CRNDE significantly decreased TCF7L2 expression at both the mRNA and protein levels (Fig. 5C and Fig. S4A, see supplementary material). But it can't decrease TCF7L2 expression after the inhibition of miR-217 (Fig. 5C and Fig. S4B, see supplementary material). To further explore the relevance of miR-217 and TCF7L2 expression level, we analyzed the TCF7L2 expression in colorectal cancer tissues (Fig. 5D) and cell lines (Fig. 5E) and found it is up-regulated with a positive 


\section{Cellular Physiology Cell Physiol Biochem 2017;41:2489-2502 \begin{tabular}{l|l|l} 
aOI: 10.1159/000475941, & $\begin{array}{l}\text { @ 2017 The Author(s). Published by S. Karger AG, Basel } \\
\text { www.karger.com/cpb }\end{array}$ \\
\hline
\end{tabular} \\ Yu et al.: CRNDE Promotes Colorectal Carcinoma Progression}

Fig. 5. miR-217 directly target A TCF7L2 and negatively regulate its expression. (A) Schematic illustration of the predicted binding sites between 3'UTR ofTCF7L2 and miR-217, and mutation of potential miR-217 binding sequence in TCF7L2. (B) Luciferase assays in HCT-116 and Caco2 cells transfected TCF7L2 wild type or mutants with miR217 mimics. (B) Western blotting and real-time PCR analyses of the relative TCF7L2 expression. Expression levels of TCF7L2 was determined by real-time PCR in 21 colorectal cancer tissues (C) and a series of human colorectal cancer cell lines (HT29, SW480, HCT-116, SW620, LoVo, SW48, DLD-1, Caco2 and HCT-15) (D) compared to those corresponding adjacent normal tissue samples or NCM460 cells.

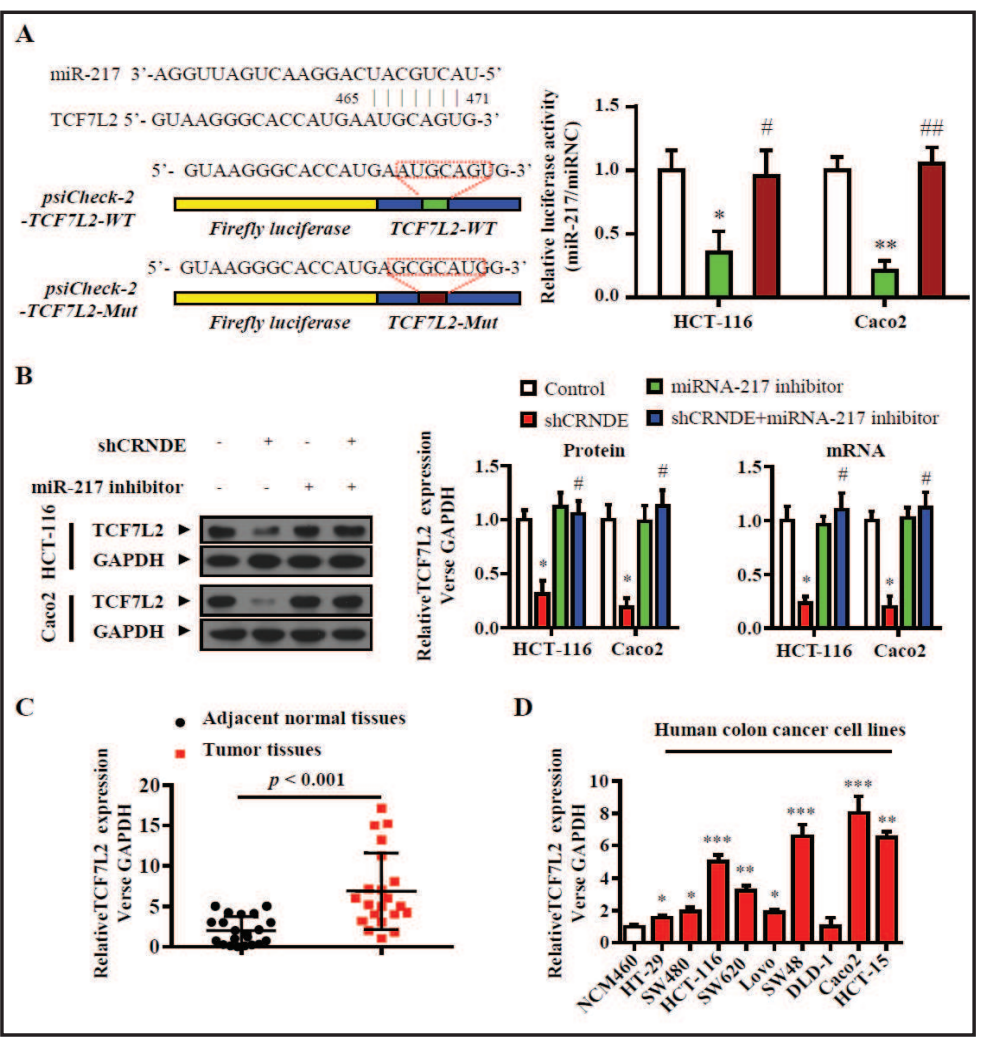

correlation with the expression of CRNDE. These results suggest that miR-217 can target TCF7L2 and negatively regulate its expression in colorectal cancer cells.

TCF7L2 overexpression completely blocks the effect of CRNDE down-regulation on colorectal cancer cells

To determine the role of TCF7L2 in CRNDE down-regulation in HCT-116 and Caco2 cells, we up-regulated the expression of TCF7L2 by transfection a plasmid of pLVX-TCF7L2 encoded the full-length coding sequence without the 3'UTR region. The overexpression efficiency of TCF7L2 was confirmed at mRNA and protein level (Fig. 6A). Meanwhile, the effect of up-regulation of TCF7L2 is highly like miR-217 inhibition which completely blocks the effect of CRNDE down-regulation with increased cell viability (Fig. 6B and Fig. S5A, see supplementary material), cell migration capability (Fig. 6C), and invasion capability (Fig. 6D) of the HCT-116 and Caco2 cells. Taken together, these data indicated that TCF7L2 repression acts as a direct and functional target of miR-217 and contributes to the inhibition of cell proliferation, migration and invasion after CRNDE down-regulation.

CRNDE down-regulation inhibits colorectal cancer cells proliferation, migration and invasion via miR-217 mediated TCF7L2 repression and subsequent inhibition of Wnt/ $\beta$ catenin signaling pathway

As TCF7L2 is an effector of the Wnt/ $\beta$-catenin signaling pathway [34], it is possible that the inhibition of colorectal cell proliferation, migration and invasion induced by CRNDE knockdown was due to increased miR-217 expression and consequent inhibition of Wnt/ $\beta$ catenin signaling pathway. To test this hypothesis, the TOPflash assay was used to evaluate the activity of Wnt/ $\beta$-catenin signaling pathway in HCT-116, Caco2 and HCT-15 cells. The results indicated that the activity of Wnt/ $\beta$-catenin signaling was significantly inhibited by CRNDE down-regulation and completely rescued by TCF7L2 overexpression (Fig. 7A and Fig. S5B, see supplementary material). Western blotting showed a marked decrease in nuclear $\beta$-catenin, the major effector of Wnt signaling, in the CRNDE down-regulated cells relative to that of the parental cells (Fig. 7B). TCF7L2 overexpression did not affect the content of 


\section{Cellular Physiology Cell Physiol Biochem 2017;41:2489-2502 \begin{tabular}{l|l} 
DOI: 10.1159/000475941 2017 & $\begin{array}{l}\text { C } 2017 \text { The Author(s). Published by S. Karger AG, Basel } \\
\text { www.karger.com/cpb }\end{array}$ \\
\hline
\end{tabular}

Fig. 6. TCF7L2 overexpression completely blocks the effect of CRNDE down-regulation on HCT-116 and $\mathrm{Caco} 2$ cells. (A) The overexpression of TCF7L2 was confirmed by western blotting and real-time quantitative PCR. (B) The cell viability was detected by the Cell Counting Kit-8 (CCK-8) assay. (C) The cell migration capability was detected by the wound healing assay. (D) The cell invasion capability was detected by wound healing assay. The data are represented as the means \pm SEM of triplicate independent experiments. ${ }^{*} \mathrm{p}<0.05 ;{ }^{* *} \mathrm{p}<0.01$ versus the scrambled group. $\# \mathrm{p}<0.05$ versus the corresponding vector control group.

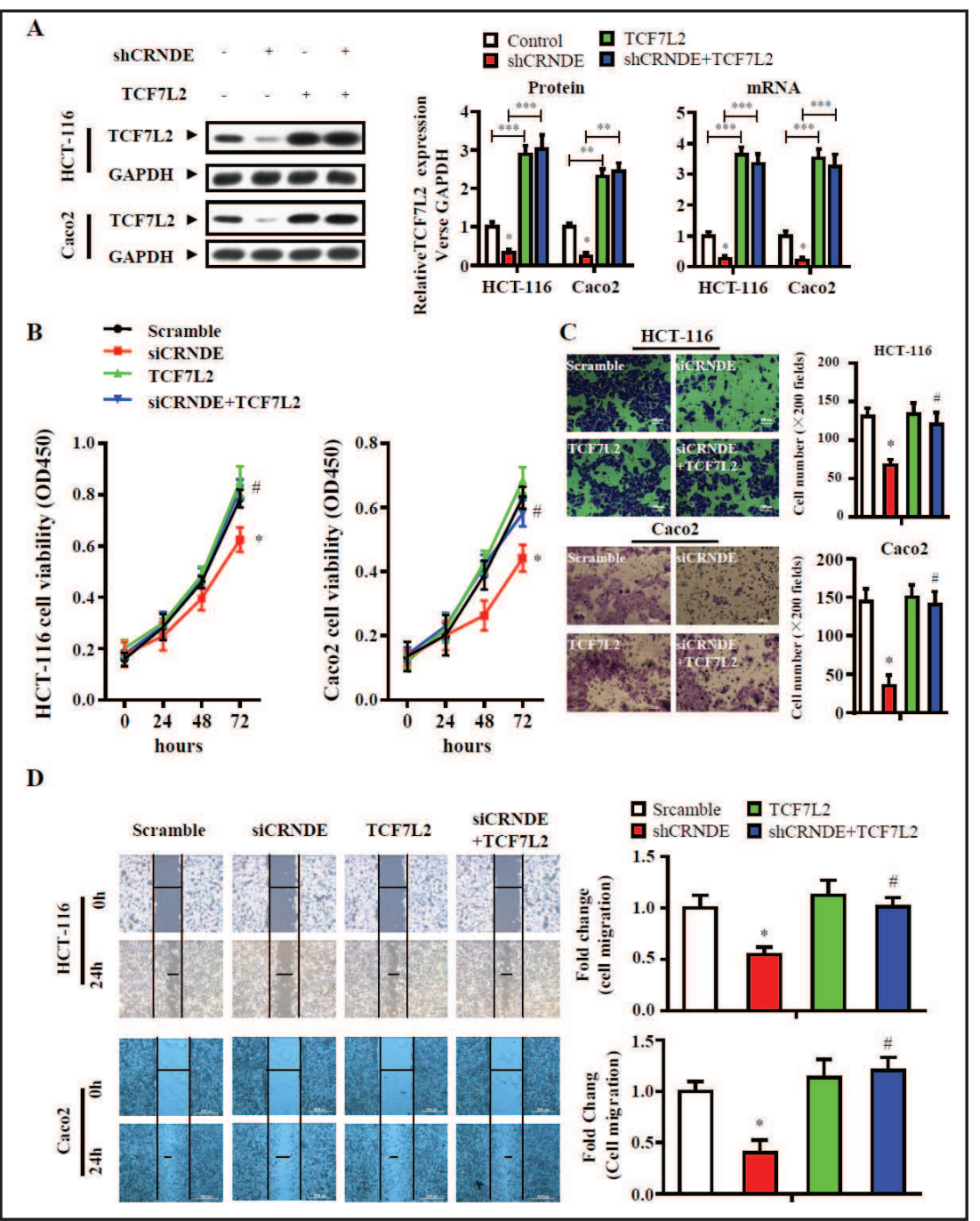

nuclear $\beta$-catenin alone but abolished the reduction of nuclear $\beta$-catenin in the CRNDE downregulation group. Furthermore, the subcellular localization of $\beta$-catenin was visualized by confocal microscopy (Fig. 7C) that was mostly accumulated in the nucleus in the control group. After CRNDE down-regulation in the HCT-116 and Caco 2 cells, $\beta$-catenin was mostly accumulated outside the nucleus. Meanwhile, TCF7L2 overexpression significantly restored the nuclear translocation of $\beta$-catenin in the CRNDE down-regulation group. Collectively, these data strongly support the hypothesis suggested that CRNDE contributes to the cell proliferation, migration and invasion of colorectal cancer cells via negative regulation of miR-217 mediated TCF7L2 repression and subsequent inhibition of Wnt/ $\beta$-catenin signaling pathway (Fig. 8).

\section{Discussion}

A significant number of lncRNAs have been identified to be able to participate in metastasis and proliferation regulation by interacting with miRNA, such as HOTAIR (HOX antisense intergenic RNA) [35, 36] and XIST (X-inactive specific transcript) [37, 38]. In this study, we found that CRNDE was highly expressed in colorectal cancer tissue and colorectal cancer cells, while miR-217 expression was low in colorectal cancer tissue and colorectal cancer cells. Moreover, CRNDE down-regulation inhibited the proliferation, migration, invasion of CRCs in vitro and in vivo and could also regulates the activity of Wnt/ $\beta$-catenin 


\section{Cellular Physiology Cell Physiol Biochem 2017;41:2489-2502 \begin{tabular}{l|l|l} 
and Biochemistry $10.1159 / 000475941$ & $\begin{array}{l}\text { D } 2017 \text { The Author(s). Published by S. Karger AG, Basel } \\
\text { www.karger.com/cpb }\end{array}$
\end{tabular}

Fig. 7. CRNDE down-regulation inhibits colorectal cancer cells proliferation, migration and invasion via miR-217 mediated TCF7L2 repression and subsequent inhibition of Wnt $/ \beta$-catenin signaling pathway. (A) The TOPflash assay was used to measure Wnt/ $\beta$ catenin signaling activity. (B) Western blots showed the levels of $\beta$-catenin and TCF7L2 from nuclear or cytoplasmic extracts. (C) The HCT-116 and Caco 2 cells were immunostained with anti- $\beta$-catenin antibody, and the subcellular localization of $\beta$-catenin was visualized by confocal microscopy. Nuclei were visualized using $4^{\prime} 6^{\prime}$-diamidino-2-phenylindole staining. ${ }^{*} \mathrm{p}<0.05,{ }^{* *} \mathrm{p}<$ 0.01 versus the scrambled group; ${ }^{*} \mathrm{p}<0.05$, \#\# $\mathrm{p}<0.01$ versus the corresponding vector control group.

signaling by binding and suppressing the miR-217's target gene TCF7L2. These findings suggested that CRNDE had a possible oncogenic role in colorectal cancers.

RNAs may crosstalk with each other through shared miRNAs, thereby modulating the bioavailability of miRNAs for their targets and imposing various levels of posttranscriptional regulation. Based on their functions, miRNAs could be grouped as onco-miRs (oncogene-like microRNAs) and tumor suppressor-miRs (tumor suppressor like microRNA] [29, 32, 35-38]. Herein, we showed that miR217 was a novel tumor suppressormiRin colorectal cancer thatinhibited

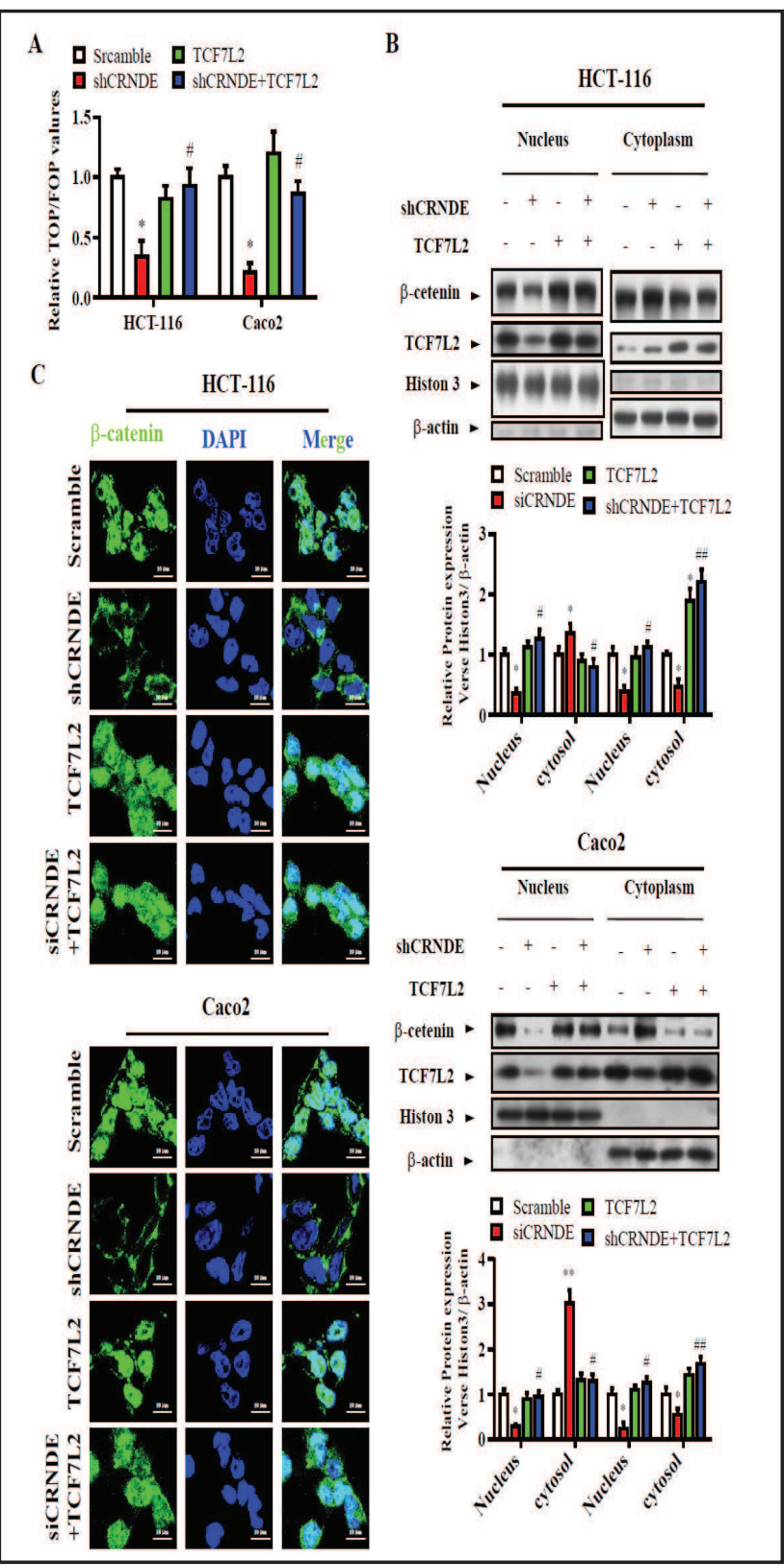

cancer progression via directly targeting the TCF7L2 gene and subsequent inhibiting the Wnt/ $\beta$-catenin signaling pathway. To the best of our knowledge, miR-217 is the first miRNA that directly targets TCF7L2. Consistent with our findings, miR-217 was shown to be a tumor suppressor in hepatocellular carcinoma [39]. The expression of miR-217 was much lower in highly invasive cell lines and metastatic tissues. In vitro and in vivo studies showed that miR-217 could directly target E2F3 and consequently inhibit tumor invasion [39]. However, in another study of pancreatic ductal adenocarcinoma, miR-217 was reported to inhibit the functions of KRAS, the loss of which enhanced tumor proliferation [40]. By contrast, miR217 was demonstrated to act as an oncogene in aggressive human B-cell lymphomas, and it down-regulated the expression of a DNA damage response and repair gene network and, in turn, stabilized Bcl-6 [41]. Considering these reported differences in a few types of cancers, we hypothesize that the role of miR-217 might be cancer species dependent and further investigations are required.

The transcription factor 7-like 2 (TCF7L2) gene, previously called TCF-4, may affect cancer progression because the TCF7L2 gene product is involved in the Wnt/ $\beta$-catenin 


\section{Cellular Physiology Cell Physiol Biochem 2017;41:2489-2502 \begin{tabular}{c|l|l} 
DOI: 10.1159/000475941 & $\begin{array}{l}\text { () } 2017 \text { The Author(s). Published by S. Karger AG, Basel } \\
\text { www.karger.com/cpb }\end{array}$
\end{tabular}}

Fig. 8. A schematic model showing that colorectal neoplasia differentially expressed (CRNDE) competitively binds to miR-217 and TCF7L2 and consequently regulates the $\mathrm{Wnt} / \beta$-catenin signaling pathway in colorectal cancer cells.

signaling pathway [42]. Dysregulation of the Wnt/ $\beta$-catenin pathway and TCF target genes plays a role in carcinogenesis and is especially well documented for colorectal cancer [43-46]. It is well known that the Wnt/ $\beta$-catenin signaling pathway is constitutively active in most tumor cells $[47,48]$. TCF7L2, one member of the Wnt signaling pathway,

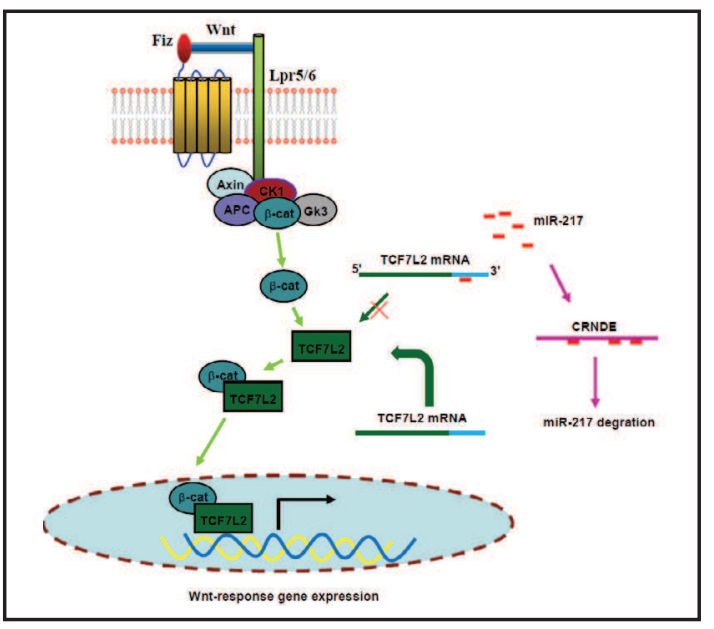
represents a central factor in metabolism,

stress responses, cell differentiation/proliferation, and cell death [34]. Here we show that the expression level of nuclear $\beta$-catenin protein and Wnt/ $\beta$-catenin signaling activity were significantly decreased by the down-regulation of CRNDE. In addition, TCF7L2 overexpression reversed the decrease in cell viability and increase in cell migration and invasion in the cells with CRNDE inhibition. These findings implied that Wnt/ $\beta$-catenin signaling was inhibited by CRNDE down-regulation via suppressing TCF7L2 in colorectal cancer.

In conclusion, the present study reported that CRNDE is involved in the development of colorectal cancer cells via miR-217 mediated Wnt/ $\beta$-catenin regulation. CRNDE may be a potential miRNA inhibitor, which needs to be considered in oncotherapy that focuses on metastasis inhibition.

\section{Acknowledgement}

This study was supported by the National Natural Science Foundation (81201807 to BY) and Science and Technology Commission of Shanghai Municipality (14411970300 \& 14401972400 to QZ) and Shanghai Municipal Commission of Health and Family Planning (2016ZB0301-02 to QZ).

\section{Disclosure Statement}

No conflicts of interest were present.

\section{References}

1 Walsh JM, Terdiman JP: Colorectal cancer screening: scientific review. JAMA 2003;289:1288-1296.

2 Bruckbauer S, Theisen C: Cancer in the developing world: how should care be delivered and research conducted? J Natl Cancer Inst 2003;95:1651-1653.

-3 Cai Z, Han S, Li Z, He L, Zhou J, Huang W, Xu Y: A genome-wide assessment of variations of primary colorectal cancer maintained in metastases. Gene 2016;595:18-24.

4 Wei W, Yang Y, Cai J, Cui K, Li RX, Wang H, Shang X, Wei D: MiR-30a-5p Suppresses Tumor Metastasis of Human Colorectal Cancer by Targeting ITGB3. Cell Physiol Biochem 2016;39:1165-1176.

5 Yang L, Parkin DM, Li L, Chen Y: Time trends in cancer mortality in China: 1987-1999. Int J Cancer 2003;106:771-783.

6 Gray RT, Coleman HG, Hughes C, Murray LJ, Cardwell CR: Statin use and survival in colorectal cancer: Results from a population-based cohort study and an updated systematic review and meta-analysis. Cancer Epidemiol 2016;45:71-81. 


\section{Cellular Physiology Cell Physiol Biochem 2017;41:2489-2502 \begin{tabular}{c|l} 
DOI: 10.1159/000475941 & $\begin{array}{l}\text { () 2017 The Author(s). Published by S. Karger AG, Basel } \\
\text { www.karger.com/cpb }\end{array}$
\end{tabular}}

Yu et al.: CRNDE Promotes Colorectal Carcinoma Progression

7 Djebali S, Davis CA, Merkel A, Dobin A, Lassmann T, Mortazavi A, Tanzer A, Lagarde J, Lin W, Schlesinger F, Xue C, Marinov GK, Khatun J, Williams BA, Zaleski C, Rozowsky J, Roder M, Kokocinski F, Abdelhamid RF, Alioto T, Antoshechkin I, Baer MT, Bar NS, Batut P, Bell K, Bell I, Chakrabortty S, Chen X, Chrast J, Curado J, Derrien T, Drenkow J, Dumais E, Dumais J, Duttagupta R, Falconnet E, Fastuca M, Fejes-Toth K, Ferreira P, Foissac S, Fullwood MJ, Gao H, Gonzalez D, Gordon A, Gunawardena H, Howald C, Jha S, Johnson R, Kapranov P, King B, Kingswood C, Luo OJ, Park E, Persaud K, Preall JB, Ribeca P, Risk B, Robyr D, Sammeth M, Schaffer L, See LH, Shahab A, Skancke J, Suzuki AM, Takahashi H, Tilgner H, Trout D, Walters N, Wang H, Wrobel J, Yu Y, Ruan X, Hayashizaki Y, Harrow J, Gerstein M, Hubbard T, Reymond A, Antonarakis SE, Hannon G, Giddings MC, Ruan Y, Wold B, Carninci P, Guigo R, Gingeras TR: Landscape of transcription in human cells. Nature 2012;489:101-108.

8 Martens-Uzunova ES, Bottcher R, Croce CM, Jenster G, Visakorpi T, Calin GA: Long noncoding RNA in prostate, bladder, and kidney cancer. Eur Urol 2014;65:1140-1151.

-9 Esteller M: Non-coding RNAs in human disease. Nat Rev Genet 2011;12:861-874.

10 Gibb EA, Brown CJ, Lam WL: The functional role of long non-coding RNA in human carcinomas. Mol Cancer 2011;10:38.

11 Li C, Chen J, Zhang K, Feng B, Wang R, Chen L: Progress and Prospects of Long Noncoding RNAs (lncRNAs) in Hepatocellular Carcinoma. Cell Physiol Biochem 2015;36:423-434.

12 Wang S, Liu F, Deng J, Cai X, Han J, Liu Q: Long Noncoding RNA ROR Regulates Proliferation, Invasion, and Stemness of Gastric Cancer Stem Cell. Cell Reprogram 2016;18:319-326.

13 Bartel DP: MicroRNAs: target recognition and regulatory functions. Cell 2009;136:215-233.

14 Shukla GC, Singh J, Barik S: MicroRNAs: Processing, Maturation, Target Recognition and Regulatory Functions. Mol Cell Pharmacol 2011;3:83-92.

15 Yu F, Fan X, Chen B, Dong P, Zheng J: Activation of Hepatic Stellate Cells is Inhibited by microRNA-378a-3p via Wnt10a. Cell Physiol Biochem 2016;39:2409-2420.

16 Xie T, Huang M, Wang Y, Wang L, Chen C, Chu X: MicroRNAs as Regulators, Biomarkers and Therapeutic Targets in the Drug Resistance of Colorectal Cancer. Cell Physiol Biochem 2016;40:62-76.

-17 Han R, Sun Q, Wu J, Zheng P, Zhao G: Sodium Butyrate Upregulates miR-203 Expression to Exert AntiProliferation Effect on Colorectal Cancer Cells. Cell Physiol Biochem 2016;39:1919-1929.

18 Liu X, Xie T, Mao X, Xue L, Chu X, Chen L: MicroRNA-149 Increases the Sensitivity of Colorectal Cancer Cells to 5-Fluorouracil by Targeting Forkhead Box Transcription Factor FOXM1. Cell Physiol Biochem 2016;39:617-629.

19 Li HT, Zhang H, Chen Y, Liu XF, Qian J: MiR-423-3p enhances cell growth through inhibition of p21Cip1/ Waf1 in colorectal cancer. Cell Physiol Biochem 2015;37:1044-1054.

20 Zhang W, Zou C, Pan L, Xu Y, Qi W, Ma G, Hou Y, Jiang P: MicroRNA-140-5p inhibits the progression of colorectal cancer by targeting VEGFA. Cell Physiol Biochem 2015;37:1123-1133.

-21 Wang D, Wang D, Wang N, Long Z, Ren X: Long Non-Coding RNA BANCR Promotes Endometrial Cancer Cell Proliferation and Invasion by Regulating MMP2 and MMP1 via ERK/MAPK Signaling Pathway. Cell Physiol Biochem 2016;40:644-656.

22 Wang KC, Yang YW, Liu B, Sanyal A, Corces-Zimmerman R, Chen Y, Lajoie BR, Protacio A, Flynn RA, Gupta RA, Wysocka J, Lei M, Dekker J, Helms JA, Chang HY: A long noncoding RNA maintains active chromatin to coordinate homeotic gene expression. Nature 2011;472:120-124.

23 Guttman M, Donaghey J, Carey BW, Garber M, Grenier JK, Munson G, Young G, Lucas AB, Ach R, Bruhn L, Yang X, Amit I, Meissner A, Regev A, Rinn JL, Root DE, Lander ES: lincRNAs act in the circuitry controlling pluripotency and differentiation. Nature 2011;477:295-300.

-24 Graham LD, Pedersen SK, Brown GS, Ho T, Kassir Z, Moynihan AT, Vizgoft EK, Dunne R, Pimlott L, Young GP, Lapointe LC, Molloy PL: Colorectal Neoplasia Differentially Expressed (CRNDE), a Novel Gene with Elevated Expression in Colorectal Adenomas and Adenocarcinomas. Genes Cancer 2011;2:829-840.

-25 Ellis BC, Molloy PL, Graham LD: CRNDE: A Long Non-Coding RNA Involved in CanceR, Neurobiology, and DEvelopment. Front Genet 2012;3:270.

-26 Cabili MN, Trapnell C, Goff L, Koziol M, Tazon-Vega B, Regev A, Rinn JL: Integrative annotation of human large intergenic noncoding RNAs reveals global properties and specific subclasses. Genes Dev 2011;25:1915-1927. 


\section{Cellular Physiology Cell Physiol Biochem 2017;41:2489-2502 \begin{tabular}{c|l} 
DOI: 10.1159/000475941 & $\begin{array}{l}\text { () 2017 The Author(s). Published by S. Karger AG, Basel } \\
\text { www.karger.com/cpb }\end{array}$
\end{tabular}}

Yu et al.: CRNDE Promotes Colorectal Carcinoma Progression

27 Liu T, Zhang X, Gao S, Jing F, Yang Y, Du L, Zheng G, Li P, Li C, Wang C: Exosomal long noncoding RNA CRNDE-h as a novel serum-based biomarker for diagnosis and prognosis of colorectal cancer. Oncotarget 2016;7:85551-85563.

-28 Wang Y, Wang Y, Li J, Zhang Y, Yin H, Han B: CRNDE, a long-noncoding RNA, promotes glioma cell growth and invasion through mTOR signaling. Cancer Lett 2015;367:122-128.

29 Yoon JH, Abdelmohsen K, Gorospe M: Functional interactions among microRNAs and long noncoding RNAs. Semin Cell Dev Biol 2014;34:9-14.

-30 Zhu J, Zhou Q, Tan S: Targeting miRNAs associated with surface expression of death receptors to modulate TRAIL resistance in breast cancer. Cancer Lett 2016;383:154-160.

-31 Thomson DW, Dinger ME: Endogenous microRNA sponges: evidence and controversy. Nat Rev Genet 2016;17:272-283.

-32 Su Z, Zhi X, Zhang Q, Yang L, Xu H, Xu Z: LncRNA H19 functions as a competing endogenous RNA to regulate AQP3 expression by sponging miR-874 in the intestinal barrier. FEBS Lett 2016;590:1354-1364.

-33 Yang C, Wu D, Gao L, Liu X, Jin Y, Wang D, Wang T, Li X: Competing endogenous RNA networks in human cancer: hypothesis, validation, and perspectives. Oncotarget 2016;7:13479-13490.

34 Hrckulak D, Kolar M, Strnad H, Korinek V: TCF/LEF Transcription Factors: An Update from the Internet Resources. Cancers (Basel) 2016;8: doi: 10.3390/cancers8070070.

-35 Tang L, Shen H, Li X, Li Z, Liu Z, Xu J, Ma S, Zhao X, Bai X, Li M, Wang Q Ji J: MiR-125a-5p decreases after long non-coding RNA HOTAIR knockdown to promote cancer cell apoptosis by releasing caspase 2. Cell Death Dis 2016;7:e2137.

36 Su DN, Wu SP, Chen HT, He JH: HOTAIR, a long non-coding RNA driver of malignancy whose expression is activated by FOXC1, negatively regulates miRNA-1 in hepatocellular carcinoma. Oncol Lett 2016;12:40614067.

37 Song P, Ye LF, Zhang C, Peng T, Zhou XH: Long non-coding RNA XIST exerts oncogenic functions in human nasopharyngeal carcinoma by targeting miR-34a-5p. Gene 2016;592:8-14.

38 Yao Y, Ma J, Xue Y, Wang P, Li Z, Liu J, Chen L, Xi Z, Teng H, Wang Z, Li Z, Liu Y: Knockdown of long noncoding RNA XIST exerts tumor-suppressive functions in human glioblastoma stem cells by up-regulating miR-152. Cancer Lett 2015;359:75-86.

39 Su J, Wang Q Liu Y, Zhong M: miR-217 inhibits invasion of hepatocellular carcinoma cells through direct suppression of E2F3. Mol Cell Biochem 2014;392:289-296.

40 Zhao WG, Yu SN, Lu ZH, Ma YH, Gu YM, Chen J: The miR-217 microRNA functions as a potential tumor suppressor in pancreatic ductal adenocarcinoma by targeting KRAS. Carcinogenesis 2010;31:1726-1733.

-41 de Yebenes VG, Bartolome-Izquierdo N, Nogales-Cadenas R, Perez-Duran P, Mur SM, Martinez N, Di Lisio L, Robbiani DF, Pascual-Montano A, Canamero M, Piris MA, Ramiro AR: miR-217 is an oncogene that enhances the germinal center reaction. Blood 2014;124:229-239.

-42 Zhao C, Deng Y, Liu L, Yu K, Zhang L, Wang H, He X, Wang J, Lu C, Wu LN, Weng Q Mao M, Li J, van Es JH, Xin M, Parry L, Goldman SA, Clevers H, Lu QR: Dual regulatory switch through interactions of Tcf 7l2/Tcf4 with stage-specific partners propels oligodendroglial maturation. Nat Commun 2016;7:10883.

43 Chen CS, Huang CY, Huang SP, Lin VC, Yu CC, Chang TY, Bao BY: Genetic interaction analysis of TCF7L2 for biochemical recurrence after radical prostatectomy in localized prostate cancer. Int J Med Sci 2015;12:243247.

-44 Chen C, Cao F, Bai L, Liu Y, Xie J, Wang W, Si Q Yang J, Chang A, Liu D, Liu D, Chuang TH, Xiang R, Luo Y: IKKbeta Enforces a LIN28B/TCF7L2 Positive Feedback Loop That Promotes Cancer Cell Stemness and Metastasis. Cancer Res 2015;75:1725-1735.

45 Weng Q, Tan B, Wang J, Wang J, Zhou H, Shi J, He Q, Yang B: 5-Fluorouracil causes severe CNS demyelination by disruption of TCF7L2/HDAC1/HDAC2 complex in adolescent mice. Toxicology 2014;325:144-150.

-46 Lewis A, Freeman-Mills L, de la Calle-Mustienes E, Giraldez-Perez RM, Davis H, Jaeger E, Becker M, Hubner NC, Nguyen LN, Zeron-Medina J, Bond G, Stunnenberg HG, Carvajal JJ, Gomez-Skarmeta JL, Leedham S, Tomlinson I: A polymorphic enhancer near GREM1 influences bowel cancer risk through differential CDX2 and TCF7L2 binding. Cell Rep 2014;8:983-990.

47 Niu X, Liu S, Jia L, Chen J: Role of MiR-3619-5p in beta-Catenin-Mediated Non-Small Cell Lung Cancer Growth and Invasion. Cell Physiol Biochem 2015;37:1527-1536.

-48 Spranger S, Bao R, Gajewski TF: Melanoma-intrinsic beta-catenin signalling prevents anti-tumour immunity. Nature 2015;523:231-235. 